\title{
Entrepreneurship development in Japan: An empirical analysis
}

\author{
Tareq Lubbadeh
}

\begin{abstract}
A B S T R A C T
Objective: The purpose of this article is to evaluate the entrepreneurship development of Japan and comparing its performance against leading countries in the same region, mainly Hong Kong, and Taiwan.

Research Design \& Methods: We implement the Global Entrepreneurship Index GEI methodology, where the GEI methodology focuses on quality-related institutional and individual aspects of entrepreneurship. Moreover, we utilised a novel feature of the GEI the Penalty for Bottleneck PFB methodology to produce induction of which entrepreneurial elements should be addressed and how much effort needs it to lighten Japan bottleneck.
\end{abstract}

Findings: Japan's entrepreneurial performance is relatively modest compared to some countries in the same region, especially in individual variables. Japan's entrepreneurial profile strengths are in the institutional features (e.g., country risk), while the instability in the profile back to individual variables (e.g., population perception and motivation). The country has three fundamental bottlenecks in its performance opportunity perception, start-up skills, and networking pillars. The GEI data used in the study only covers the 2006-2016 period. Japan should be focused on the three bottlenecks opportunity perception, start-up skills, and networking to improve its entrepreneurial performance by developing an education policy that focuses on entrepreneurship.

Contribution \& Value Added: This paper identifies the vulnerable aspects of Japan's performance by using a novel methodology that combines individual and institutional variables in a single model. Also, the use of (PFB) to detect which entrepreneurial components should be addressed.

\begin{tabular}{lll}
\hline $\begin{array}{l}\text { Article type: } \\
\text { Keywords: }\end{array}$ & research article \\
JEL codes: & Japan; Entrepreneurship; GEI; GEM; Penalty for Bottleneck \\
\hline \multicolumn{2}{c}{ L26, O1, F01 } & \\
\hline \multicolumn{2}{|c|}{ Article received: 6 October 2019} & Article accepted: 2 December 2019 \\
\hline
\end{tabular}

\section{Suggested citation:}

Lubbadeh, T. (2019). Entrepreneurship development in Japan: An empirical analysis. International Entrepreneurship Review (previously published as International Entrepreneurship / Przedsiębiorczość Międzynarodowa), 5(3), 19-33. https://doi.org/10.15678/IER.2019.0503.02 


\section{INTRODUCTION}

Entrepreneurship is influenced by the country in which it operates, as well as in the region where it is situated. Japan is a world apart culture with its original civilisation and history. The country, is positioned in East Asia not very far from Korea or China, has an innovationdriven economy (Tilak, 2002). Also viewed as one of the most advanced economies in Asia and the world, the country spending on R\&D in 2017, exceeds $3 \%$ of GDP surpasses the total OECD countries (OECD, 2019b). In 2018 the GDP per capita amounted to 4.971 trillion US dollars, with a GDP growth rate $0.78 \%$ and purchasing power parity (PPP) of 5.415 trillion dollars in 2018 (OECD, 2019a; World Bank, 2019a). Since the early 1990s, the Japanese government has promoted entrepreneurship policy as an integral part of economic development policy (Aoyama, 2009). Also, the current prime mister, Shinzō Abo, is committed to support the entrepreneurship activity as his government placed a goal of doubling the business entry rate and TEA rate in 2020 (Kegel, 2016).

Although this development in the economy and the government interest in promoting entrepreneurship, still the entrepreneurship levels in Japan are inferior to other countries like Taiwan and Korea. According to the GEM data, the level of entrepreneurial activity in Japan was disproportionately low for Innovation-driven economies. Where the rate (TEA) throughout the last 18 years did not exceed 5.4\% (Global Entrepreneurship Monitor [GEM], 2018). There are different explanations for the low ratio, such as community ageing, Japan culture, education orientation, and the population attitudes toward entrepreneurship (Martin, 2019; Shinato, Kamei, \& Dana, 2013). Most of the studies that examined entrepreneurship were based on individual or institutional data (Honjo, 2015), but the current study relies on the GEI methodology, which combines both individual and institutional variables in a single model.

This paper utilises an innovative methodology; the Global Entrepreneurship Index (GEI), to examine and evaluate the overall entrepreneurship performance of the country and to measure the country's entrepreneurship level (ecosystem). This approach is unique as it blends quality-related institutional and individual factors, which allows measuring the performance on the individual and institutional levels in a single model, while the GEM survey designed to collect individual data about the population (Szerb \& Trumbull, 2018). Also, we used this approach to compare the country's profile to leading countries in the same region. The results show that the country profile is modest compared to Hongkong and Taiwan. Moreover, through this methodology, we were able to distinguish and identify the strengths and the weakness of the country performance. The results reveal that Japan has significant hold-up in individual entrepreneurship features. Finally, we used a unique feature of the GEI, the bottleneck methodology PFB to simulate a situation where a country can improve its performance by allocating more entrepreneurship resources to the weakest links in the model. The simulation implies that Japan should focus its resources on opportunity perception, start-up skills, and networking pillars to improve its performance. Thus we were able to provide a thorough and multilevel view about the country entrepreneurial performance. Added to that, producing policy recommendations that can help in intensifying its entrepreneurship performance by targeting the most vulnerable link in the system.

The paper is formed as follows. First, it presents the literature, followed by an examination of the country entrepreneurship profile based on some of the Global 
Entrepreneurship Monitor (GEM) measures and indicators. After that, it discusses the (GEI) methodology. In the fifth part, the paper investigates Japan's performance-based on the GEl. Next, it compares the country performance to Hong Kong and Taiwan. Following, it uses the bottleneck methodology PFB to identify the most vulnerable links in the system to seize the system performance and simulate a scenario where Japan can increase its GEI score by allocating more entrepreneurship resources. The conclusion in the last part.

\section{LITERATURE REVIEW}

Japan is known for having entrepreneurship hindrance (Honjo, 2015; Nakayama, 2016; Shinato et al., 2013). A vast number of studies investigated the entrepreneurship situation in Japan. The shortage of entrepreneurship in the country manifests itself in different tangible pieces. According to the GEM : 2001 Executive Report, the culture in Japan is unfavourable for entrepreneurs, and the entrepreneurs themself do not possess the necessary facilities to start and operate a business (Reynolds, Camp, Bygrave, Autio, \& Hay, 2002). Shinato et al. (2013), pointed out that the traditional cultural climate hindered the development of entrepreneurship in the country, and the entrepreneurship education is limited to MBA or MOT courses (Shinato et al., 2013). Honjo (2015), examined the individual factors that influence entrepreneurial activities in Japan using the GEM data. Honjo found that entrepreneurial activities and attitudes in the country are low. He also noticed that Japanese people who are perceived to have the needed skills and knowledge to start up a business are more apt to start a business compared to other countries (Honjo, 2015).

Nakayama (2016), studied the factors that contribute to the entrepreneurial intention of university students in Japan. Nakayama found that entrepreneurial self-efficacy, having a specific business idea, and entrepreneurial education has a significant part of the student intention. Nevertheless, he also suggested that the fear of failure contributes largely to diverting the interest of some students away from entrepreneurship (Nakayama, 2016).

Kegel (2016), conducted a multilevel compersion on the startup entrepreneurial activity between the United States and Japan. The study found that the United States presents a dynamic environment to support entrepreneurial activity in several entrepreneurial activity factors such as culture, education, and entry regulation. However, Japan showed instability in entrepreneurial education, entry regulation, culture, but it showed positive signs in physical infrastructure, government policy, and R \& D transfer. Kegel also argued on the value of immigration to entrepreneurial activity (Kegel, 2016). According to the above, we can note that the entrepreneurship in Japan, features lack in entrepreneurship education, also unfavourable culture and attitude toward entrepreneurship.

\section{JAPAN ENTREPRENEURIAL PROFILE BASED ON GEM}

The Global Entrepreneurship Monitor (GEM) is an international research program that monitors and examines the relationship between entrepreneurship and the development in the economy by measuring entrepreneurial activities across countries (Marvel, 2012). The GEM was launched in 1998 and provided corresponded data on people's attitudes, perceptions, and motivation toward entrepreneurship, and entrepreneurial activity, that can be employed to examine the entrepreneurship development in 
a single state, and cross-sectional states (Reynolds et al., 2005; Singer, Herrington, \& Menipaz, 2018; Sternberg \& Wennekers, 2005).

The principal objective of the GEM program has been to examine "differences in national levels and types of entrepreneurship and to link these to job creation and economic growth "(Singer et al., 2018, p. 33).

In this section of the article, we portray Japan's entrepreneurial performance through some of GEM entrepreneurship individual measures.

Perceived capabilities, this percentage totalled only 10\% in 2018 (Bosma \& Kelley, 2018). Which reflects that only $10 \%$ of the adult population believes that they hold the required abilities and experience to start a business, this ratio is inferior to the regional and global averages, $49.15 \%$ and $49.19 \%$ respectively. This indicates that there is a lack of exposure to entrepreneurialism in the early stages of education. Fear of failure, this indicator shows that anxiety of failure would hinder the adult population from initiating up a business. As Japan seized $46.4 \%$ in 2018 ; this ratio is high compared to the regional and global averages of $38.1 \%$ and $36.2 \%$ sequentially (Bosma \& Kelley, 2018, p. 88). Perceived Opportunities, presents the proportion of the adult population (18-64), who sees an excellent opportunity to start a firm (Singer et al., 2018). This ratio stood at 8.1\%; in 2018 (Bosma \& Kelley, 2018, p. 88).

Total early-stage entrepreneurial activity (TEA), the TEA indicator describes the portion of the adult population who either a nascent entrepreneur or running a business (Singer et al., 2018; Szerb \& Trumbull, 2018). The TEA ratio for Japan reached only $5.3 \%$ in 2018, while the regional average in the same year was, $12.65 \%$ (Bosma \& Kelley, 2018 , p. 88), this can be attributed to several reasons previously stated. The TEA rate in Japan is disappointingly low, but this measure reflects only the percentage of the population involved in entrepreneurship activities (necessity entrepreneurs), not the quality of entrepreneurship activities (Ács, Szerb, \& Lloyd, 2017). Established Business Ownership (EB), only $6.2 \%$ of Japan's population are currently owner-manager of an established business in 2018, where the regional and the global average $9.34 \%$ and $8.50 \%$, respectively (Bosma \& Kelley, 2018, p. 88). Employee entrepreneurial activity (EEA), in 2018 , was only $2.17 \%$ of the adult population involved in entrepreneurial activities (Bosma \& Kelley, 2018).

The self-employment rate indicates the ratio of workers who work for themselves. This percentage in Japan only accounted for 10.2\% in 2018 (World Bank, 2019c); this corresponds with the TEA measure; as we mentioned shortly, the TEA ratio is moderate in Japan matched to the neighbouring countries. So it is reasonable to have a low self-employment rate, where the number of people engaged in entrepreneurship activities is small, and where the majority of the population turned to the dominant companies to work in.

According to the above individual measures and indicators, we can note that Japan's performance is infernal in comparison with the regional and global average. However, the self-employment rate and TAE only measures the quantitative aspects of entrepreneurship. According to Ács et al. (2017), countries require fewer self-employment rates and more qualitative aspects. They found that TEA correlates negatively with development measures, specifically, the index of economic Freedom $(-0.27)$, global competitiveness index (-0.46), and ease of doing business index (-0.57) (Ács et al., 2017, pp. 31). 


\section{MATERIAL AND METHODS}

The Global Entrepreneurship Index GEI was developed by Ács, Autio and Szerb (Ács, Autio, \& Szerb, 2014; Ács, Rappai, \& Szerb, 2011; Ács \& Szerb; 2009) to capture countrylevel entrepreneurship (Szerb, Komlósi, \& Páger, 2016). Ács et al. (2014) define the entrepreneurial ecosystems as "dynamic institutionally embedded interaction between entrepreneurial attitudes, abilities, and aspirations, by individuals, which drives the allocation of resources through the creation and operation of new ventures" (Ács et al., 2014 , p. 11). As every ecosystem consists of different pillars, the GEI consists of 14 pillars, formed by individuals and institutions variables, which interacts with each other to create an entrepreneurship ecosystem, which the entrepreneurial activity is the output of the ecosystem (Ács et al., 2017).

The GEl is a composite indicator of the health of the entrepreneurship ecosystem in a given country (Ács, Szerb, Lafuente, \& Lloyd, 2018). It is a multilevel structure consists of three sub-indexes (Attitudes, Abilities, and Aspirations) (3As), which comprises 14 "pillars" ${ }^{11}$ that merge both individual-level and country-level institutional variables ( Szerb et al., 2016; Szerb \& Trumbull, 2018).

The GEI methodology focuses on the quality aspects of entrepreneurship instead of quantity. The GEM measures the quantity aspects of entrepreneurship. For example, as previously seen, Japan's self-employment rate is low, and this does not reflect the economic development as the Japanese economy is the third-largest in the world regarding GDP. The methodology focuses on the quality aspects of entrepreneurship not on the number of small enterprises (vending machine) but on the quality of innovative enterprises that adds value to society (Ács et al., 2017).

The GEI takes into account both individuals and institutions aspects of entrepreneurship, while the GEM focuses on collecting individual measures of the population. The GEI adds macro-level institutional dimensions such as (culture, education, and market size) (Szerb et al., 2016; Szerb \& Trumbull, 2018), hence the GEI is a valuable tool to help countries accurately assess and evaluate their ecosystem to add value to society.

The GEI is a compound index consists of a four-level index (Ács et al., 2017, p. 93):

- variables,

- pillars,

- sub-indices,

- super-index.

Each of the three sub-indices ${ }^{2}$ contains individual and institutional variables. The Entrepreneurial attitudes sub-index: reflects the individual's orientation towards entrepreneurship. The Entrepreneurial abilities sub-index: reflect the entrepreneurs' characteristics to turn the opportunity into action. Finally, Entrepreneurial aspiration sub-index: reflect the entrepreneur's efforts to start a new venture. (Ács et al., 2014, 2017).

A novel feature of the GEI method is employing the Penalty for Bottleneck PFB methodology; the GEI can distinguish the weakest link (lowest value) in the system to capture the system performance. The worst performing pillars serve as a bottleneck that holds

\footnotetext{
${ }^{1}$ For detailed description about the methodology of the pillars, see (Ács et al., 2014).

2 For more detail about the constructing of sub-indexes ATT, ABT, and ASB see (Ács \& Szerb, 2009).
} 
back the ecosystem performance. Therefore, the best performing pillars are "penalised" because of the distortion. The extent of the penalty depends on the differences between the bottleneck pillar and a particular pillar, the higher the magnitude of the bottleneck, the greater is the penalty (Ács et al., 2014; Szerb et al., 2016).

The PFB draws policy attention to infirmities aspects of the entrepreneurial ecosystem through which appropriate policies can be developed to address it (Ács et al., 2017; Szerb \& Trumbull, 2018). These features make the GEI a proper approach to analysis the entrepreneurial ecosystems.

\section{JAPAN'S ENTREPRENEURIAL PERFORMANCE BASED ON GEI}

In this section of the article, we will analyse Japan's entrepreneurial performance by relying on the GEI. The analysis will focus on the 2012-2016 GEI data for Japan.

Table 1 displays the rank of the countries' overall GEI scores for the 2012-2016 averages; we have data for 95 countries in this period. Also, the table shows the Global Competitiveness Index classification, where 1 indicates resource-driven countries (least developed nations), 2 indicates efficiency-driven countries (increasingly competitive), and 3 indicates Innovation-driven economies (most developed nations) (Szerb \& Trumbull, 2018).

Table 1. Japan position in in global entrepreneurship index rank 2012-2016 average

\begin{tabular}{|c|l|c|c|c|c|l|c|c|c|}
\hline Rank & \multicolumn{1}{|c|}{ Country } & $\begin{array}{c}\text { GDP per } \\
\text { capita }\end{array}$ & GEI & Stage & Rank & Country & $\begin{array}{c}\text { GDP per } \\
\text { capita }\end{array}$ & GEI & Stage \\
\hline 1 & United States & 51,88 & 82.5 & 3 & 49 & Uruguay & 19,491 & 34.1 & 2 \\
\hline 2 & Switzerland & 56,39 & 78.9 & 3 & 50 & Barbados & 15,35 & 34 & 2 \\
\hline 3 & Canada & 42,83 & 78.3 & 3 & 51 & South Africa & 12,38 & 33.4 & 2 \\
\hline 4 & Australia & 43,88 & 74.9 & 3 & 52 & Croatia & 20,52 & 32.3 & 2 \\
\hline 5 & Sweden & 44,57 & 74.7 & 3 & 53 & Costa Rica & 14,13 & 31.5 & 2 \\
\hline 6 & Denmark & 44,70 & 73.7 & 3 & 54 & Lebanon & 13,03 & 31 & 2 \\
\hline 7 & United Kingdom & 37,84 & 72.2 & 3 & 55 & Kazakhstan & 23,50 & 30 & 1 \\
\hline 8 & Ireland & 52,55 & 70.3 & 3 & 56 & Belize & 7,941 & 29.8 & 2 \\
\hline 9 & Netherlands & 45,95 & 69.2 & 3 & 57 & Namibia & 9,113 & 29.4 & 2 \\
\hline 10 & Finland & 39,35 & 68.1 & 3 & 58 & Macedonia & 12,31 & 29.1 & 2 \\
\hline 11 & Hong Kong & 54,27 & 67.3 & 3 & 59 & Morocco & 7,276 & 28.2 & 2 \\
\hline 12 & France & 37,57 & 65.2 & 3 & 60 & Thailand & 15,000 & 27.7 & 2 \\
\hline 13 & Austria & 44,21 & 65.2 & 3 & 61 & Peru & 11,55 & 27.4 & 2 \\
\hline 14 & Germany & 43,40 & 64.2 & 3 & 62 & Mexico & 16,52 & 26.6 & 2 \\
\hline 15 & Belgium & 41,21 & 63.3 & 3 & 63 & Bulgaria & 17,35 & 26.5 & 2 \\
\hline 16 & Taiwan & 37,83 & 63 & 3 & 64 & Panama & 19,82 & 26.4 & 2 \\
\hline 17 & Israel & 31,67 & 61.1 & 3 & 65 & India & 5,578 & 26.3 & 1 \\
\hline 18 & Chile & 22,16 & 59 & 2 & 66 & Georgia & 9,008 & 25.3 & 2 \\
\hline 19 & Luxembourg & 94,27 & 58.5 & 3 & 67 & Trinidad \& Tobago & 31,59 & 25.3 & 2 \\
\hline 20 & Norway & 63,17 & 58.2 & 3 & 68 & Russia & 24,732 & 24.7 & 2 \\
\hline 21 & Estonia & 26,772 & 56 & 3 & 69 & Egypt & 10,079 & 24.2 & 2 \\
\hline 22 & Qatar & 119,53 & 55.4 & 3 & 70 & Philippines & 6,589 & 23.9 & 1 \\
\hline 23 & Korea & 33,372 & 53.6 & 3 & 71 & Argentina & 19,017 & 23.8 & 2 \\
\hline 24 & Slovenia & 28,592 & 52.9 & 3 & 72 & Iran & 16,184 & 22.5 & 2 \\
\hline 25 & Singapore & 78,294 & 52.1 & 3 & 73 & Ghana & 3,720 & 22.5 & 1 \\
\hline 26 & Japan & 36,946 & 49.4 & 3 & 74 & Algeria & 13,207 & 22.2 & 1 \\
\hline
\end{tabular}




\begin{tabular}{|c|l|c|c|c|c|l|c|c|c|}
\hline Rank & \multicolumn{1}{|c|}{ Country } & $\begin{array}{c}\text { GDP per } \\
\text { capita }\end{array}$ & GEI & Stage & Rank & Country & $\begin{array}{c}\text { GDP per } \\
\text { capita }\end{array}$ & GEI & Stage \\
\hline 27 & Cyprus & 31,196 & 48 & 3 & 75 & Vietnam & 5,386 & 22.2 & 1 \\
\hline 28 & Portugal & 26,208 & 47 & 3 & 76 & Nigeria & 5,409 & 22 & 1 \\
\hline 29 & Poland & 24,484 & 46.9 & 2 & 77 & Jamaica & 8,090 & 21.7 & 2 \\
\hline 30 & Lithuania & 25,150 & 46.4 & 2 & 78 & Bolivia & 6,325 & 21.4 & 1 \\
\hline 31 & Spain & 31,691 & 45.6 & 3 & 79 & Indonesia & 10,195 & 21.1 & 2 \\
\hline 32 & Turkey & 21,871 & 45 & 2 & 80 & El Salvador & 7,743 & 20.7 & 2 \\
\hline 33 & Puerto Rico & 33,844 & 44.6 & 3 & 81 & $\begin{array}{l}\text { Bosnia and Herze- } \\
\text { govina }\end{array}$ & 10,224 & 20.7 & 2 \\
\hline 34 & United Arab Emirates & 67,133 & 44.6 & 3 & 82 & Ecuador & 10,630 & 20.5 & 2 \\
\hline 35 & Slovakia & 27,489 & 42.8 & 3 & 83 & Brazil & 14,922 & 20.4 & 2 \\
\hline 36 & Latvia & 22,298 & 42.3 & 2 & 84 & Zambia & 3,543 & 20.3 & 1 \\
\hline 37 & Czech Republic & 28,380 & 40.4 & 3 & 85 & Senegal & 2,297 & 19.7 & 1 \\
\hline 38 & Saudi Arabia & 50,458 & 40.2 & 2 & 86 & Guatemala & 7,203 & 18.4 & 2 \\
\hline 39 & Hungary & 23,946 & 39.4 & 2 & 87 & Suriname & 15,371 & 17.9 & 2 \\
\hline 40 & Tunisia & 10,577 & 38.8 & 2 & 88 & Pakistan & 4,367 & 17.5 & 1 \\
\hline 41 & Colombia & 12,592 & 38.3 & 2 & 89 & Libya & & 17.2 & 1 \\
\hline 42 & Italy & 34,452 & 38.1 & 3 & 90 & Malawi & 1,051 & 16.6 & 1 \\
\hline 43 & Jordan & 8,390 & 36.5 & 2 & 91 & Ethiopia & 1,231 & 15.5 & 1 \\
\hline 44 & China & 12,765 & 35.9 & 2 & 92 & Cameroon & 740 & 15.3 & 1 \\
\hline 45 & Greece & 24,092 & 35.9 & 3 & 93 & Uganda & 1,646 & 13.9 & 1 \\
\hline 46 & Malaysia & 24,132 & 35.5 & 2 & 94 & Angola & 6,148 & 13.8 & 1 \\
\hline 47 & Romania & 19,376 & 35.0 & 2 & 95 & Burkina Faso & 1,560 & 12.5 & 1 \\
\hline 48 & Botswana & 15,271 & 34.3 & 1 & & & & & \\
\cline { 1 - 5 } & & & & & &
\end{tabular}

Note: GDP per capita in international \$ World Bank.

Source: own elaboration based on (Szerb \& Trumbull, 2018).

The highlighted countries with light grey are all located in East Asia. We can notice that Japan is an innovation-driven economy and occupies 26th place in the global rankings, with a (49.4) GEI score, behind Hong Kong, Taiwan, and Korea.

Japan's overall performance at the 26th in the world and the fourth in East Asia is a little surprise for an innovation-driven country.

Table 2 presents more details about Japan's entrepreneurial performance at subindexes and pillars level.

Table 2 illustrates the three sub-indices (Attitudes, Abilities, and Aspiration) components, the 14 pillars, and their scores.

The pillars shaded in dark grey scored the lowest results (lousy performance); the shaded in light grey have an average score, while the pillars in white achieved the highest results.

The attitude sub-index pillars, opportunity perception, start-up skills, and networking are critically low bottleneck pillars. At the same time, Japan scores high in risk acceptance; which combines the population risk perception (fear of fail) with the country's business risk (Ács et al., 2017).

In the ability sub-index, Japan scores high in all the pillars except competition, indicating that an influential business group governs the market or/and vice in competition regulation. Only one component in aspiration sub-index scored low, risk capital; which can reflect inadequate financial resources (Ács \& Szerb, 2009; Shinato et al., 2013). 
Table 2. Japans entrepreneurial profile at sub-indexes and pillars level 2012-2016

\begin{tabular}{|l|l|c|}
\hline \multicolumn{1}{|c|}{ Sub-indexes } & \multicolumn{1}{|c|}{ PILLARS } & Score \\
\hline \multirow{5}{*}{ Entrepreneurial Attitudes (ATT) } & Opportunity Perception & 0.17 \\
\cline { 2 - 3 } & Start-up skills & 0.12 \\
\cline { 2 - 3 } & Risk Acceptance & 0.64 \\
\cline { 2 - 3 } & Networking & 0.30 \\
\cline { 2 - 3 } & Cultural Support & 0.37 \\
\cline { 2 - 3 } & ATT & $\mathbf{2 8 . 9}$ \\
\hline \multirow{5}{*}{ Entrepreneurial Abilities (ABT) } & Opportunity Startup & 0.61 \\
\cline { 2 - 3 } & Technology Absorption & 0.95 \\
\cline { 2 - 3 } & Human Capital & 0.93 \\
\cline { 2 - 3 } & Competition & 0.52 \\
\cline { 2 - 3 } & ABT & $\mathbf{5 7 . 9}$ \\
\hline \multirow{5}{*}{ Entrepreneurial Aspirations (ASB) } & 0.90 \\
\cline { 2 - 3 } & Product Innovation & 1.00 \\
\cline { 2 - 3 } & Process Innovation & 0.98 \\
\cline { 2 - 3 } & High Growth & 0.66 \\
\cline { 2 - 3 } & Internationalization & 0.57 \\
\cline { 2 - 3 } & Risk Capital & $\mathbf{6 1 . 5}$ \\
\cline { 2 - 3 } & ASB & $\mathbf{4 9 . 4}$ \\
\hline
\end{tabular}

Note: Pillars and sub-indexes are normalised values.

Source: own elaboration based on GEI data 2012-2016 averages.

Table 3 presents a further thorough analysis of Japan's entrepreneurial profile at the institutional and individual levels.

Almost all of Japan's institutional variables are among the best countries (top 25\%) except three institutional variables shaded in light grey are among the top $50 \%$; this is expected from the well-developed and innovative country and well-equipped to support entrepreneurial activity.

Japan is among the worst countries in six individual variables (worst 25\%) shaded in darkest grey and just in one variable below the average shaded in dark grey.

Five of the individual variables shaded in the greyest zone, are all in the ATT subindex. This means that the entrepreneur's traits and attitudes toward entrepreneurial activities are shallow compared to other countries, which are consistent with Honjo (2015), and Nakayama (2016). This can be associated with various reasons. Such as reduced exposure to entrepreneurship, especially at a young age, and overlooking the entrepreneurial culture in schools, as well as to particular causes related to the Japanese culture such as low tolerance of failure, which has a profound impact on the social relationship (Ács et al., 2017; Shinato et al., 2013).

In the attitudes sub-index, only one individual variable has deficient scores (competitors), indicating the Japanese market characterised by high barrier entry that restricts start-up businesses from entering and compete with other companies or similar non-innovative products in the market consist with Kegel (2016). The highest-scoring sub-index is entrepreneurial aspirations attributed to the entire individual and institutional variables except for the export variable. 
Table 3. Japan's entrepreneurial profile at the variable level based on 2012-2016 averages

\begin{tabular}{|l|c|l|c|l|c|}
\hline \multicolumn{2}{|c|}{ PILLARS } & \multicolumn{2}{c|}{ INSTITUTIONAL VARIABLES } & \multicolumn{2}{c|}{ INDIVIDUAL VARIABLES } \\
\hline Opportunity Perception & 0.17 & Freedom & 0.82 & Opportunity Recognition & 0.11 \\
\hline Start-up skills & 0.12 & Education & 0.72 & Skill Perception & 0.10 \\
\hline Risk Acceptance & 0.64 & Country Risk & 1.00 & Risk Perception & 0.40 \\
\hline Networking & 0.30 & Connectivity & 1.00 & Know Entrepreneurs & 0.21 \\
\hline Cultural Support & 0.37 & Corruption & 0.84 & Career Status & 0.18 \\
\hline ATT & $\mathbf{2 8 . 9}$ & & - & - & - \\
\hline Opportunity Startup & 0.61 & Governance & 0.75 & Opportunity Motivation & 0.62 \\
\hline Technology Absorption & 0.95 & Technology Absorption & 0.99 & Technology Level & 0.92 \\
\hline Human Capital & 0.93 & Labor Market & 0.92 & Elucational Level & 0.86 \\
\hline Competition & 0.52 & Competitiveness and Regulation & 0.96 & Competitors & 0.30 \\
\hline ABT & $\mathbf{5 7 . 9}$ & & - & & - \\
\hline Product Innovation & 0.90 & Technology Transfer & 0.99 & New Product & 0.68 \\
\hline Process Innovation & 1.00 & Science & 1.00 & New Technology & 0.58 \\
\hline High Growth & 0.98 & Finance and strategy & 0.77 & Gazelle & 0.96 \\
\hline Internationalization & 0.66 & Economic complexity & 1.00 & Export & 0.61 \\
\hline Risk Capital & $\mathbf{0 . 5 7}$ & Depth of Capital Market & 0.97 & Informal Investment & 0.62 \\
\hline ASB & $\mathbf{6 1 . 5}$ & & - & & - \\
\hline GEI & $\mathbf{4 9 . 4}$ & Institutional & $\mathbf{0 . 9 1}$ & Individual & $\mathbf{0 . 5 1}$ \\
\hline
\end{tabular}

Note: white: best $25 \%$; light grey: best $50 \%$; dark grey: worst $50 \%$; most shaded grey: worst $25 \%$.

Source: own elaboration based on GEI data 2012-2016 averages

The focus should be on the individual -variables where the average of individual variables was 51 shaded in darkest grey (worst 25\%), which signifies a problem in Japan's entrepreneurial performance.

\section{COMPARING JAPAN'S ENTREPRENEURIAL PERFORMANCE TO HONG KONG AND TAIWAN}

In this section, we evaluate Japan's performance compared to Hong Kong and Taiwan at the level of the entrepreneurship pillars in figure 1.

The selection of Taiwan and Hong Kong for the comparison with Japan is due to several reasons first the geographical location of the three countries located in East Asia, the convergence of GDP per capita, Taiwan (37831.6), and Japan (36946.3), except Hong Kong (54279), the similarity of the culture of the three countries. Plus, the three countries are considered as Innovation-driven countries based on the Global Competitiveness Index Classification. Despite this similarity, Hong Kong ranked 16th with $67.3 \mathrm{GEI}$ average score, and Taiwan ranked 11th with an average of 63, ahead of Japan in the 26 places.

We can discern that Hong Kong is the top performance in Asia and globally in many pillars, such as opportunity perception, networking, and Risk Capital (perfect score pillars). Nevertheless, Hong Kong faces a significant bottleneck, first in competition pillar, which could be due to weak competition law and regulation or because of the presence of dominant companies in the markets. Second, the process innovation pillar, which reflects the adoption of new technology by start-ups and "GERD"; the amount of domestic expenditure on R\&D. The reason for this decline is low spending on research and development, as the country expenditure on R\&D was only $0.8 \%$ of GDP in 2017 (World Bank, 2019b), as 
well as Hong Kong government, is less open to innovation and adopting new technologies. Hong Kong excels Japan significantly, almost in all attitudes related pillars, except risk acceptance. Japan should follow the lead of Hong Kong in the mentioned aspects.

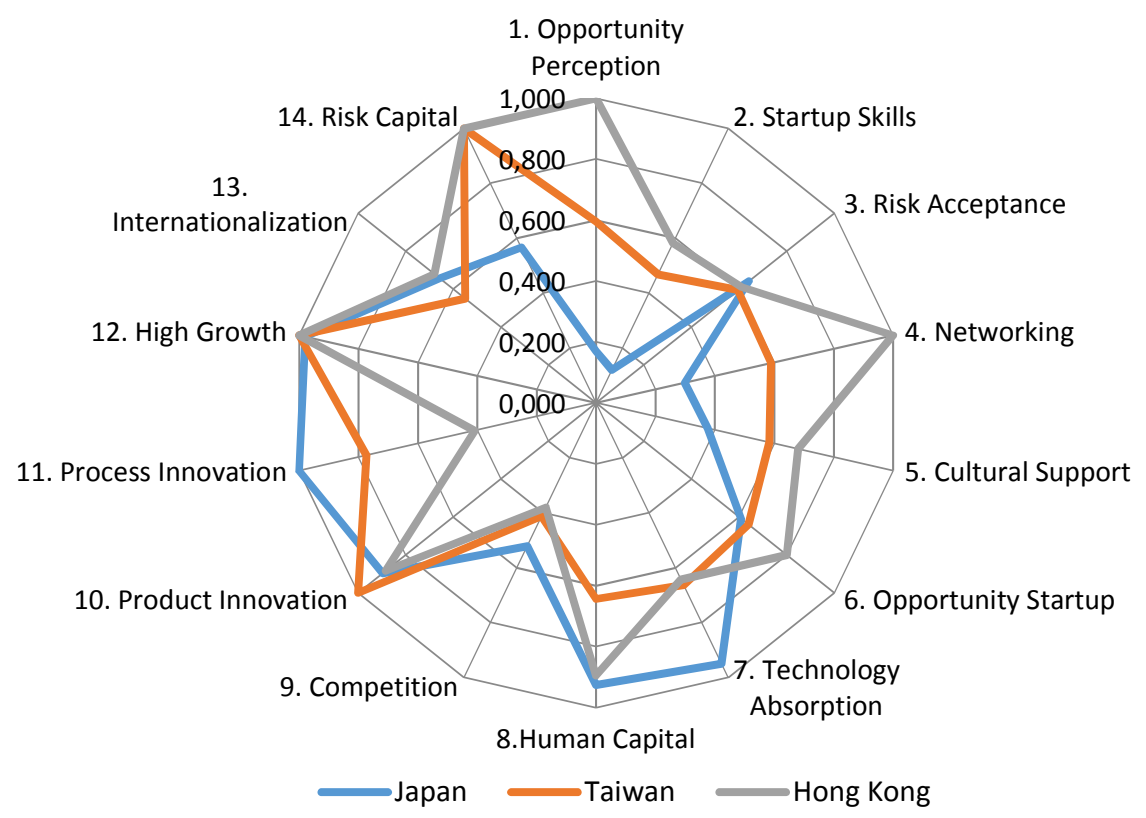

Figure 1. Pillar level compression of Japan, Taiwan, and Hong Kong Source: own elaboration based on GEI data 2012-2016 averages.

Taiwan also considered as a top performer after Hong Kong, especially in product Innovation and risk capital. Taiwan has the competition pillar as a bottleneck like Hong Kong and Japan, which indicates that a few companies have monopolistic power in the market. Besides, the start-up skills as a bottleneck resembling Japan; this can be addressed by education policy. On the other hand, Japan surpasses both Hong Kong and Taiwan in technology absorption and process innovation pillars.

\section{IMPROVING ENTREPRENEURSHIP IN JAPAN: A SIMULATION}

In the prior section, we investigated Japan's entrepreneurial performance and matched it with Hong Kong and Taiwan's performance based on the GEI index; also, we identified the depths and gaps in Japan's performance. In this part, we will try to provide policy suggestions to help Japan in improving the entrepreneurship performance by using the PFB $^{3}$ methodology, by simulating a scenario in which Japan allocate more entrepreneurship resource to gain a 10 point increase in the GEI index average, from 49.4 to 59.4.

The PFB approach assumes that entrepreneurship performance depends on the weakest pillars (poor performance). By increasing the bottleneck pillar, the whole GEI score can

\footnotetext{
${ }^{3}$ For more details about the PFB methodology and GEI method see (Ács et al., 2017, pp. 86-112)
} 
be improved (Ács, Rappai, \& Szerb, 2011; Szerb et al., 2016). In other words, what is the "optimal" allocation of entrepreneurship policy resources to achieve an increase in the GEI? and how should the added support be allocated? (Szerb et al., 2016, p. 18).

Table 4 shows Japan's bottleneck pillar and the necessary improvement in the pillars after a 10 point increase in the GEI average.

Table 4. Simulation of maximising Japan GEI index average by 10 points

\begin{tabular}{|c|c|c|c|c|}
\hline Sub-indexes new score & \multicolumn{2}{|l|}{ PILLARS } & $\begin{array}{l}\text { Required In- } \\
\text { crease in Pillar }\end{array}$ & $\begin{array}{l}\text { Percentage of the } \\
\text { total new effort }\end{array}$ \\
\hline \multirow{6}{*}{ Entrepreneurial Attitudes } & Opportunity Perception & & 0.18 & $39 \%$ \\
\hline & Start-up skills & & 0.23 & $50 \%$ \\
\hline & Risk Acceptance & & 0.0 & $0 \%$ \\
\hline & Networking & & 0.05 & $11 \%$ \\
\hline & Cultural Support & & 0.0 & $0 \%$ \\
\hline & ATT & 40.3 & & \\
\hline \multirow{5}{*}{ Entrepreneurial Abilities } & Opportunity start-up & & 0.0 & $0 \%$ \\
\hline & Technology Absorption & & 0.0 & $0 \%$ \\
\hline & Human Capital & & 0.0 & $0 \%$ \\
\hline & Competition & & 0.0 & $0 \%$ \\
\hline & ABT & 66.5 & & \\
\hline \multirow{7}{*}{ Entrepreneurial Aspirations } & Product Innovation & & 0.0 & $0 \%$ \\
\hline & Process Innovation & & 0.0 & $0 \%$ \\
\hline & High Growth & & 0.0 & $0 \%$ \\
\hline & Internationalisation & & 0.0 & $0 \%$ \\
\hline & Risk Capital & & 0.0 & $0 \%$ \\
\hline & ASB & 71.1 & & \\
\hline & GEI & 49.3 & & \\
\hline
\end{tabular}

Source: own calculations based on GEl index data 2012-2016 averages.

According to the table, the most prominent bottleneck pillars are start-up skills, opportunity perception, and networking all in the attitudes sub-index, which is consistent with Honjo (2015) and Martin (2019).

We can see that to improve Japan GEl average index by 10 points, this will call for using $50 \%$ of the total effort in the start-up skills for 0.23 required increase in the pillar, a $39 \%$ improvement in opportunity perception for an 0.18 required increase in the pillar, and the rest of the total effort needed in Networking for 0.05 required increase in the pillar.

If Japan wants to improve its entrepreneurial performance, the focus should be toward those areas. The start-up skills pillar consist of skill perception and education. This can be addressed through promoting education policy, such as adding a training curriculum to improve students' entrepreneurial skills needed to start or advance a business. Also, employing more entrepreneurs as lecturers, especially those with expertise in creating a start-up, to provide more realistic and valuable guidance (Shinato et al., 2013).

Opportunity Perception pillar consists of two variables opportunity recognition and freedom (Ács et al., 2017). The freedom variable got a high score of $82 \%$ comprised of two variables "economic freedom and property rights". Still, the drawback is in opportunity recognition, which is only $11 \%$, and this could also be approached by education policies, 
more exposure to entrepreneurial activities, and more support for venture start-ups. This will enhance the individual's ability to seize opportunities.

Finally, the Networking pillar also consists of two variables, connectivity and know Entrepreneurs. Japan has no defect in connectivity institutional variables, which expected from a civilised country with a robust infrastructure. Nevertheless, the drawback in the individual variable Know Entrepreneurs that scores only $21 \%$, shows the proportion of the people who personally know an entrepreneur who began a business within two years (Ács et al., 2017). The low score can be attributed to Japan's culture, individual culture, and limited respect to entrepreneurship as a career choice (Martin, 2019; Shinato et al., 2013). Possibly we can approach this by increasing the exposure of society to entrepreneurs' stories, and their role in society and the economy; this will improve society's respect for entrepreneurs. Also, through international and local conferences targeting young people, to introduce domestic and foreign entrepreneurs to share their experiences and ideas. This approach can help Japan in building a more effective and powerful network between entrepreneurs in Japan and outside Japan.

\section{CONCLUSIONS}

The fundamental purpose of the paper is to investigate the entrepreneurial development in Japan and suggest some recommendations that can help in enhancing its entrepreneurial performance. We used the GEI methodology to examine the country's development at the institutional and individual levels. Also, we used the PFB methodology to suggest policy recommendations by highlighting the worst-performing pillar in the system.

Based on the multi-level analysis, we found Japan's performance to be modest compared to other countries in the same region as Japan is listed in the 26th place in the global rankings after Hong Kong 11th, and Taiwan 16th. Hong Kong profile surpasses Japan profile in the attitudes sub-index. Japan should follow the lead of Hong Kong and Taiwan, especially in the attitudes related pillars. The cause for the modest performance is the population characteristics such as perception, motivation, and attitude toward entrepreneurship. Where Japan is among the worst countries (worst $25 \%$ ), in six individual variables, and has only three variables in the best $25 \%$, where the average score in the all individual variables is only (0.51). On the other hand, almost all of Japan's institutional variables are among the best $25 \%$ countries, and three variables in the best $50 \%$ countries, which is expected from an innovation-driven economy. These findings suggest that the focus should be on the individual variables, especially in entrepreneurial attitudes sub-index.

We used a novel implication of GEI, the PFB methodology; we were able to simulate a situation where Japan can improve its GEI average scores by 10 points through targeting the weakest pillars. Based on the PFB analysis, Japan has three main bottlenecks, opportunity perception, start-up skills, and networking which are all in the entrepreneurial attitudes sub-index. To improve Japan's GEI scores by 10 points, this call for directing $50 \%$ of total effort (entrepreneurship policy resources) in the opportunity perception, $39 \%$ in Start-up skills, and $11 \%$ in the networking pillars.

As a limitation, the GEI data used in the analysis covers only the 2012-2016 period. Therefore, further analysis is needed to cover a more extended or more up-to-date period than the one used in the study, especially since there was a change in the Japanese government and policies during the period 2012-2013. We compared the Japan profile only 
with Hong Kong and Taiwan and only at the level of the pillar. Accordingly, more comparison should be made with various countries outside East Asia, at all levels. Additionally, $\mathrm{GEI}$ is a good indicator to be used for start-up companies.

Despite the limitation, the article contributes to portraying Japan's entrepreneurial profile through a unique index that combines quality-related individual and institutional variables in a single model. We contribute to identifying the weak aspect in Japan's entrepreneurial profile at the sub-index, pillars, and the level of the variables. In particular, the analysis presents empirical evidence that the ground for the modest performance is due to the shortage of population entrepreneurship traits. Adding to that, we used the PFB approach to highlight the country's bottlenecks and to provide approximate suggestions on how much Japan seeks to improve its bottleneck.

\section{REFERENCES}

Ács, Z. J., Autio, E., \& Szerb, L. (2014). National Systems of Entrepreneurship: Measurement issues and policy implications. Research Policy, 43(3), 476-494. https://doi.org/10.1016/j.respol.2013.08.016

Ács, Z. J., Rappai, G., \& Szerb, L. (2011). Index-Building in a System of Interdependent Variables: The Penalty for Bottleneck. GMU School of Public Policy Research Paper, 2011-24. https://doi.org/10.2139/ssrn.1945346

Ács, Z.J., \& Szerb, L. (2009). The Global Entrepreneurship Index (GEINDEX). Foundations and Trends in Entrepreneurship, 5(5), 341-435. https://doi.org/10.1561/0300000027

Ács, Z.J., Szerb, L., Lafuente, E., \& Lloyd, A. (2018). Global Entrepreneurship Index 2018. Cham: Springer Briefs in Economics. doi:10.1007/978-3-030-03279-1

Acs, Z. J., Szerb, L., \& Lloyd, A. (2017). Global Entrepreneurship and Development Index 2017. Cham: Springer Briefs in Economics. https://doi.org/10.1007/978-3-319-65903-9

Aoyama, Y. (2009). Entrepreneurship and Regional Culture: The Case of Hamamatsu and Kyoto. Regional Studies, 43(3), 495-512. https://doi.org/10.1080/00343400902777042

Bosma, N. (2013). The Global Entrepreneurship Monitor (GEM) and its impact on entrepreneurship research. Foundations and Trends in Entrepreneurship, 9(2), 143-248. https://doi.org/10.1561/0300000033

Bosma, N., \& Kelley, D. (2018). Global Entrepreneurship Monitor: 2018/2019 Global Report. Retrieved on October 23, 2019 from http://www.gemconsortium.org/report/50012

GEM. (2018). Total Early-Stage Entrepreneurial Activity (TEA), \% Of 18-64 Population (2001-2018). Retrieved on October 31, 2019 from https://www.gemconsortium.org/data/key-aps

Honjo, Y. (2015). Why are entrepreneurship levels so low in Japan? Japan \& The World Economy, 36, 88-101. https://doi.org/10.1016/j.japwor.2015.08.002

Kegel, P. (2016). A Comparison of Startup Entrepreneurial Activity Between the United States and Japan. Journal of Management Policy and Practice, 17(1), 18-26. https://doi.org/10.33423/jmpp.v17i1.1819

Martin, J. R. G. (2019). Impact of Cultural Factors on Entrepreneurship: Evidence From GEM Model and the Singularity of Japan. In N. Baporikar (Ed.), Handbook of Research on Ethics, Entrepreneurship, and Governance in Higher Education (pp. 433-454). IGI Global. https://doi.org/10.4018/978-1-5225-5837-8.ch020

Marvel, M.R. (Ed.). (2012). Encyclopedia of New Venture Management. Los Angeles: SAGE. https://doi.org/10.4135/9781452218571

Nakayama, T. (2016). Entrepreneurial Intention in Japan: An Empirical Study on Japanese University Students. International Journal of Business and General Management, 5(3), 81-94. 
OECD. (2019a). Gross domestic product (GDP) (indicator). https://doi.org/10.1787/dc2f7aec-en

OECD. (2019b). Gross domestic spending on R\&D (indicator). https://doi.org/doi: 10.1787/d8b068b4-en

Reynolds, P., Bosma, N., Autio, E., Hunt, S., De Bono, N., Servais, I., ... Chin, N. (2005). Global entrepreneurship monitor: Data collection design and implementation 1998-2003. Small Business Economics, 24(3), 205-231. https://doi.org/10.1007/s11187-005-1980-1

Reynolds, P., Camp, M., Bygrave, W.D., Autio, E., \& Hay, M. (2002). Global Entrepreneurship Monitor : 2001 Executive Report. https://doi.org/10.13140/RG.2.1.2501.3286

Shinato, T., Kamei, K., \& Dana, L. P. (2013). Entrepreneurship education in Japanese universities - how do we train for risk taking in a culture of risk adverseness? International Journal of Entrepreneurship and Small Business, 20(2), 184-202. https://doi.org/10.1504/IJESB.2013.056278

Singer, S., Herrington, M., \& Menipaz, E. (2018). Global Entrepreneurship Monitor: 2017/2018 Report. https://doi.org/10.7507/1002-1892.201706082

Sternberg, R., \& Wennekers, S. (2005). Determinants and effects of new business creation using global entrepreneurship monitor data. Small Business Economics, 24(3), 193-203. https://doi.org/10.1007/s11187-005-1974-z

Szerb, L., Komlósi, É., \& Páger, B. (2016). Measuring Entrepreneurship and Optimizing Entrepreneurship Policy Efforts in the European Union. CESifo DICE Report, 114(3), 8-23. Retrieved on July 2, 2019 from https://www.econstor.eu/bitstream/10419/167269/1/ifodice-report-v14-y2016-i3-p08-23.pdf

Szerb, L., \& Trumbull, W. N. (2018). Entrepreneurship development in Russia: is Russia a normal country? An empirical analysis. Journal of Small Business and Enterprise Development, 37(11), 572-576. https://doi.org/10.1108/JSBED-01-2018-0033

Tilak, J.B.G. (2002). Building Human Capital in East Asia: What Others Can Learn. The International Bank for Reconstruction and Development, Washington D.C : The World Bank.

World Bank. (2019a). GDP, PPP (current international \$) - Japan [Data file]. Retrieved on October 3, 2019 from https://data.worldbank.org/indicator/NY.GDP.MKTP.PP.CD?locations=JP

World Bank. (2019b). Research and development expenditure (\% of GDP) - Hong Kong SAR, China, Japan, Korea, Rep. [Data file]. Retrieved on November 27, 2019 from https://data.worldbank.org/indicator/GB.XPD.RSDV.GD.ZS?locations=HK

World Bank. (2019c). Self-employed, total (\% of total employment) (modeled ILO estimate) - Japan [Data file]. Retrieved on October 31, 2019 from https://data.worldbank.org/indicator/SL.EMP.SELF.ZS?locations=JP 


\section{Author}

\section{Tareq Lubbadeh}

Tareq Lubbadeh is a Ph.D. Student in the Program in Business Administration at the University of Pécs. He holds an MBA degree from Al- Balqa' Applied University (BAU), Amman, Jordan. In his doctoral research, he focuses on the relation between job Burnout and employee performance. Tareq has a genuine interest in combining the art and science of psychology with useful and practical business applications to improve the work environment.

Correspondence to: Tareq Lubbadeh, University of Pécs, Pécs, Rákóczi út 80, 7622, Hungary, email: tareq.lubbadeh@yahoo.com

ORCID (1) http://orcid.org/0000-0002-8118-8775

\section{Acknowledgements and Financial Disclosure}

The authors would like to express his gratitude to Prof. Dr László Szerb, who made the GEI dataset available and for his valuable comments of this paper and his inspiration to further research study.

\section{Copyright and License}

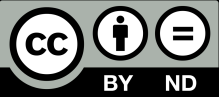

This article is published under the terms of the Creative Commons

Attribution - NoDerivs (CC BY-ND 4.0) License http://creativecommons.org/licenses/by-nd/4.0/

Published by the Centre for Strategic and International Entrepreneurship - Krakow, Poland 
